\title{
IMPACT OF THE OCCURRENCE OF TARAXACUM OFFICINALE F.H.WIGG. ON FLORISTIC DIVERSITY AND UTILISATION VALUES OF MEADOW-PASTURE COMMUNITIES
}

\author{
KRYSZAK, A. - KLARZYŃSKA, A. - STRYCHALSKA, A. - MAĆKOWIAK, Ł. ${ }^{*}$ \\ KRYSZAK J. \\ Department of Grassland and Natural Landscape Sciences, \\ Poznań University of Life Sciences \\ 11 Dojazd St. 60-632Poznań, Poland \\ (phone: +48-61-848-7415) \\ *Corresponding author: \\ e-mail:lukmac@up.poznan.pl \\ (Received 23 ${ }^{\text {rd }}$ Apr 2015; accepted 17 ${ }^{\text {th }}$ Dec 2015)
}

\begin{abstract}
The floristic composition of anthropogenic meadow communities undergoes transformations dependent on utilisation and habitat conditions. One of their consequences includes encroachment into and maintenance in the sward of some expansive plant species e.g. Taraxacum officinale. The objective of the study was to analyse the impact of the occurrence of Taraxacum officinale on the floristic diversity of meadow-pasture communities at varying levels of utilisation and habitat conditions. The effect of Taraxacum officinale presence on changes in the floristic composition of meadow communities was assessed on the basis of results of geobotanical studies carried out by Braun-Blanquet's method. The studies assumed evaluation of plant species proportions in the sward of meadow communities based on the share of Taraxacum officinale, floristic diversity and the natural value index of the sward. The highest share of analysed plant species was determined in extensively utilised meadows and pastures found on periodically dry habitats. Simultaneously, the high numbers of examined plant species exert a negative influence on the floristic diversity index and the natural value of plant communities.
\end{abstract}

Keywords: common dandelion, expansive plant species, habitat conditions, manner of use, meadow communities

\section{Introduction}

The floristic composition of anthropogenic communities, including grass communities, undergoes slow, but continuous changes, which scope is dependent e.g. on habitat conditions as well as the type and intensity of utilisation (Barabasz, 1994, 1997). Transformations of the floristic composition connected with quantitative changes in individual species of meadow and pasture swards result, among other things, from the encroachment of new species exhibiting high adaptability (Baker, 1965, 1974). Their spread is most frequently connected with the increase in the population of the species, leading to penetration of areas adjacent to the boundaries of the original range or even colonisation of new, previously unoccupied habitats within the natural range limits of the species (Pysek et al., 1995; Jackowiak, 1999; Genovesi, 2004). These species, thanks to their adaptability, become common, thus reducing the natural value of communities (Kryszak et al., 2009). An example of the species which tend to colonise new habitats is Taraxacum officinale F.H.Wigg. This species exhibits high competitiveness, as a result of which it is found at a high proportion and in considerable clusters in swards of permanent grassland (Vavrek et al., 1996; Molina-Montenegro et al., 2011, 2013; Martinkova and Honek, 2014). 
Thus the aim of this study was to determine causes for the increasing share of Taraxacum officinale in meadow and pasture communities and its effect on the utilisation value of the sward and floristic diversity.

\section{Materials and methods}

The occurrence of Taraxacum officinale (common dandelion) was determined based on a comparative analysis of 1000 relevés, prepared following Braun-Blanquet's method (1964), and which were entered in the Turboveg data base (Hennekens, Schamiane, 2001). Using the Twinspan programme (Hill, 1979) a preliminary hierarchic classification analysis was conducted, which showed similarities and differences between the relevés. Identified groups of relevés were classified to the phytosociological system based on the study by Matuszkiewicz (2012).

Relevés selected for further analyses represented 5 meadow-pasture communities from the class Molinio-Arrhenatheretea differing in the type and intensity of use (Table 1).

Table 1. Analysed meadow-pasture communities

\begin{tabular}{lc}
\hline \multicolumn{1}{c}{ Community } & Manner of use \\
\hline Ass.: Alopecuretum pratensis (Regel 1925) Steffen 1931 & cut $3 \times$ \\
Ass.: Arrhenatheretum elatioris Br.-Bl.ex Scherr.1925 & cut $2 \times$ \\
Com. Deschampsia caespitosa & cut $1 \times$ \\
Ass.: Lolio-Cynosuretum R.Tx.1937 & pasture; $2-3$ LSU/ha \\
Com. Poa pratensis-Festuca rubra Fijałk. 1962 & pasture; 1 LSU/ha \\
\hline
\end{tabular}

Notes. LSU - livestock units.

Relevés in the communities were grouped depending on the occurrence of common dandelion in the phytocoenosis:

A - none,

$\mathrm{B}$ - share with quantity $\mathrm{r}$ and + ,

$\mathrm{C}-$ share with quantity 1 and 2 .

Phytocoenoses were characterised in terms of the mean sward cover in the relevé and floristic abundance based on the total number of plant species in the community and mean number in the relevé, as well as the Shannon-Wiener floristic diversity index (Magurran, 1991; Szoszkiewicz and Szoszkiewicz 1998). Natural value (NVI) was assessed using valuation numbers according to Oświt (2000). This method ascribes numerical values from 1 to 10 to each taxon depending on the natural value of the plant species. The most valuable, protected and endangered species receive the highest values, while common species are ascribed the value of 1 . Natural value of phytocoenoses was determined as the arithmetic mean of the numbers ascribed to species.

The fodder value was assessed using the method, which ascribes to each plant species values from -3 to 10 (Filipek, 1973). Negative numbers refer to poisonous species, numbers 0 and 1 are given to taxa with the lowest fodder value, while $10-$ to species with the highest fodder value. The fodder value of sward (FVS) in the evaluated phytocoenoses was obtained as the weighted mean taking into consideration the proportion of the plant species and the ascribed number representing its fodder value. 
Habitat conditions of the phytocoenoses were determined by the phytoindicator method and laboratory methods. Using the indicator number according to Ellenberg and Leuschner (2010) the following values were calculated for each relevé: insolation (L), moisture content $(\mathrm{F})$, pH-reaction $(\mathrm{R})$ and soil nitrogen content $(\mathrm{N})$. In turn, laboratory methods were used to determine the following:

- soil moisture content - by the oven-dry method,

- soil reaction, i.e. soil $\mathrm{pH}$ in $1 \mathrm{~mol} \mathrm{KCl} \mathrm{dm}^{-3}$ - by potentiometry

- organic substance content in soil - by the gravimetric method consisting in roasting of samples at $600^{\circ} \mathrm{C}$ and calculation of weight losses,

- potassium content (by flame photometry) and phosphorus content (by colorimetry):

- in mineral soils - the Egner-Riehm method,

- in organic soils in $0.5 \mathrm{~mol} \mathrm{HCl} \mathrm{dm}^{-3}$,

- content of available magnesium

- in mineral soils - the Schachtschabel method,

- in organic soils in $0.5 \mathrm{~mol} \mathrm{HCl} \mathrm{dm}^{-3}$.

Results were analysed using PCA and RDA with the use of the Canoco for Windows 5 programme (Braak and Šmilauer, 2012), which makes it possible to arrange the collection of relevés in relation to habitat factors and determine the dependence of natural value and fodder value in communities with different shares of Taraxacum officinale on habitat conditions.

\section{Results and discussion}

\section{Occurrence of Taraxacum officinale in meadow communities}

Results of analyses conducted in the five communities indicate that the share of Taraxacum officinale is connected with the manner of utilisation and its intensity. Occurrence of the species is particularly promoted by pasture use. An increase in its share in the sward was also found at the lower number of cuttings and cattle stocking (Table 2). Such a dependence indicates a potential for the control of this species in swards of grassland through increased intensity of use (Jankowska, 2012). Klimeš et al. (2003) showed that in the unharvested vegetation covers rate of Taraxacum officinale can increase. Moreover, those authors confirmed combined way of manner (once mowing and once grazing) actually contibute to proliferate and increase common dandelion share.

Table 2. Natural and useful characteristics of studied plant communities

\begin{tabular}{lccccccc}
\hline Community + utilisation & \multicolumn{3}{c}{$\begin{array}{c}\text { Number of plant species } \\
\text { generally } \\
\text { average in } \\
\text { relevés }\end{array}$} & $\begin{array}{c}\text { Cover } \\
{[\%]}\end{array}$ & $\mathrm{H}^{\prime *}$ & $\begin{array}{c}\text { NVI } \\
* *\end{array}$ & $\begin{array}{c}\text { FVS } \\
* * *\end{array}$ \\
\hline Alopecuretum pratensis & $\mathrm{A}$ & 76 & 21 & 88.1 & 2.2 & 2.26 & 7.23 \\
$2-3 \times$ cutting & $\mathrm{B}$ & 64 & 23 & 80.0 & 2.3 & 2.41 & 7.17 \\
& $\mathrm{C}$ & 60 & 20 & 81.9 & 2.2 & 1.98 & 7.64 \\
Arrhenatheretum elatioris & $\mathrm{A}$ & 67 & 24 & 82.5 & 2.4 & 1.93 & 6.99 \\
$2 \times$ cutting & $\mathrm{B}$ & 77 & 26 & 76.9 & 2.4 & 1.77 & 7.42 \\
& $\mathrm{C}$ & 65 & 24 & 74.4 & 2.3 & 2.00 & 7.59 \\
Deschampsia caespitosa & $\mathrm{A}$ & 79 & 24 & 81.2 & 2.3 & 2.13 & 3.74 \\
$1 \times$ cutting or no cutting & $\mathrm{B}$ & 60 & 22 & 80.6 & 2.5 & 2.37 & 3.80 \\
& $\mathrm{C}$ & 62 & 19 & 76.2 & 2.1 & 2.50 & 4.35
\end{tabular}




\begin{tabular}{llllllll} 
Lolio-Cynosuretum & A & 66 & 22 & 88.1 & 2.3 & 1.94 & 8.05 \\
grazing: 2-3 LSU/ha & B & 77 & 31 & 86.2 & 2.7 & 1.95 & 7.44 \\
& C & 64 & 22 & 84.4 & 2.3 & 1.75 & 7.92 \\
Poa pratensis-Festuca rubra & A & 68 & 21 & 85.0 & 2.4 & 2.00 & 6.48 \\
grazing: 1 LSU/ha & B & 50 & 24 & 82.5 & 2.4 & 2.00 & 8.14 \\
& C & 60 & 22 & 76.8 & 2.4 & 2.01 & 7.41 \\
\hline
\end{tabular}

Notes. * H' - floristic diversity index - according to Shannon-Wiener; **NVI - nature value index according to Oświt (2000); *** FVS - fodder value score - according to Filipek (1973); LSU livestock units.

In low and less dense swards used as pastures in the phytocoenosis LolioCynosuretum and the community Poa pratensis - Festuca rubra a higher share of this species was recorded, particularly at a low total vegetation cover in the phytocoenosis (Fig. 1). As it was reported by Jankowska et al. (2009), this process may be explained by allelopathic properties of common dandelion or its adaptation to changing habitat conditions. Changes in habitat conditions cause elimination of plant species of high natural value, as a result of which free spaces appear for species with a wide ecological scale. These conditions are used e.g. by common dandelion, which occupies the free spaces and as a consequence dominate the phytocoenosis.

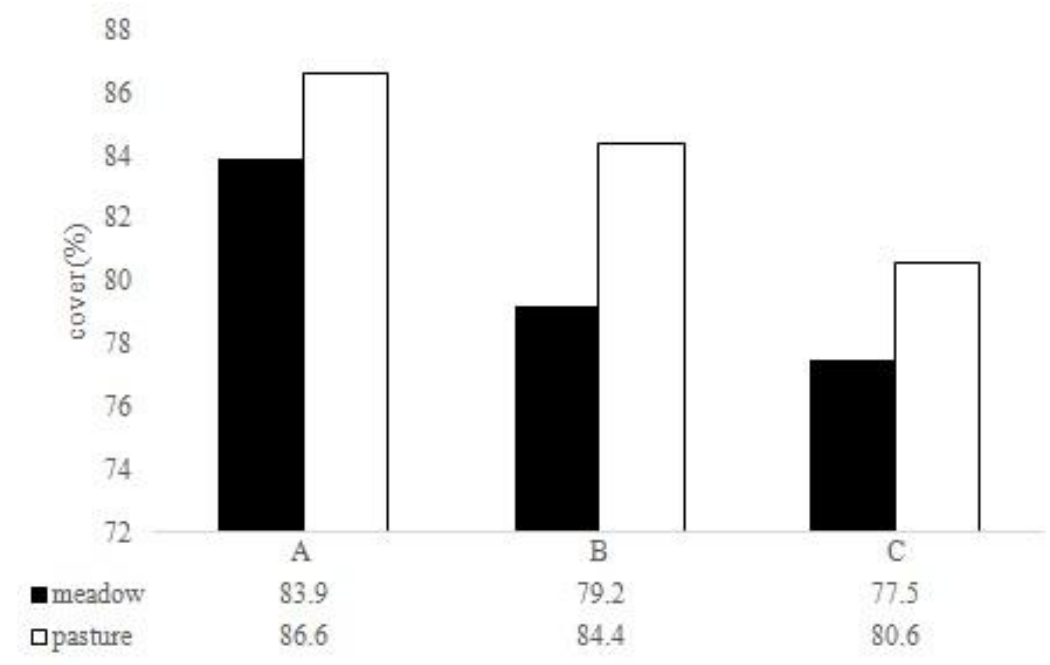

Figure 1. The dependence of the share of Taraxacum officinale on sward cover of the releve area. Notes. A-group of relevés without Taraxacum officinale; $B$-group of relevés with ' $r$ ' and ' + ' share of Taraxacum officinale; $C$-group of relevés with ' 1 ' and ' 2 ' share of Taraxacum officinale.

The dependence of the occurrence of Taraxacum officinale on habitat conditions is presented in Figs. 2, 3 and 4. They show that insolation and soil reaction are the most significant habitat factors having a positive effect on the share of dandelion. In turn, a negative effect on the presence of this species is found for habitat moisture content and contents of available magnesium forms in soil. The other habitat factors, i.e. the level of available nitrate nitrogen, potassium and phosphorus has no effect on its share in the sward. This species was recorded in phytocoenoses developed in habitats with the lowest moisture contents and as a rule with soils containing low levels of the analysed macronutrients (Fig. 2). 
Moreover, it was found that periodically dry and strongly insolated areas are characterised by a lesser turf cover and promote an increased share of Taraxacum officinale.

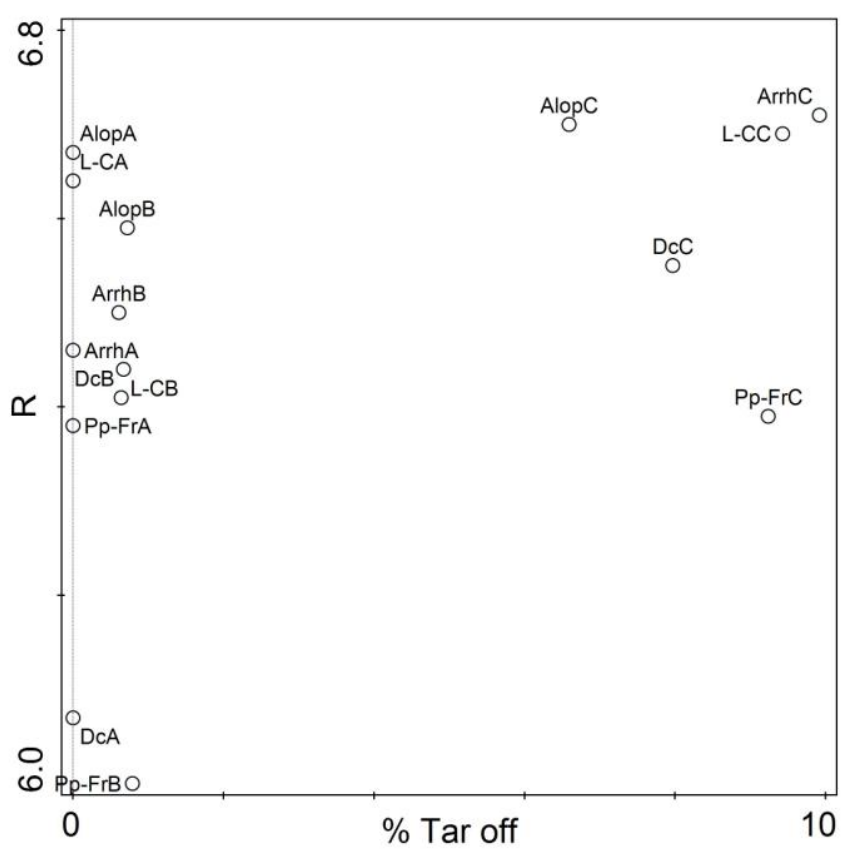

Figure 2. The share of Taraxacum officinale in swards of phytocoenoses depending on $p H$ reaction. Notes. Alop - Alopecuretum pratensis; Arrh - Arrhenatheretum elatioris; Dccommunity Deschampsia caespitosa; L-C - Lolio-Cynosuretum; Pp-Fr-community Poa pratensis-Festuca rubra; A - group of relevés without Taraxacum officinale; $B$ - group of relevés with ' $r$ ' and ' + ' share of Taraxacum officinale; $C$-group of relevés with ' 1 ' and ' 2 ' share of Taraxacum officinale.

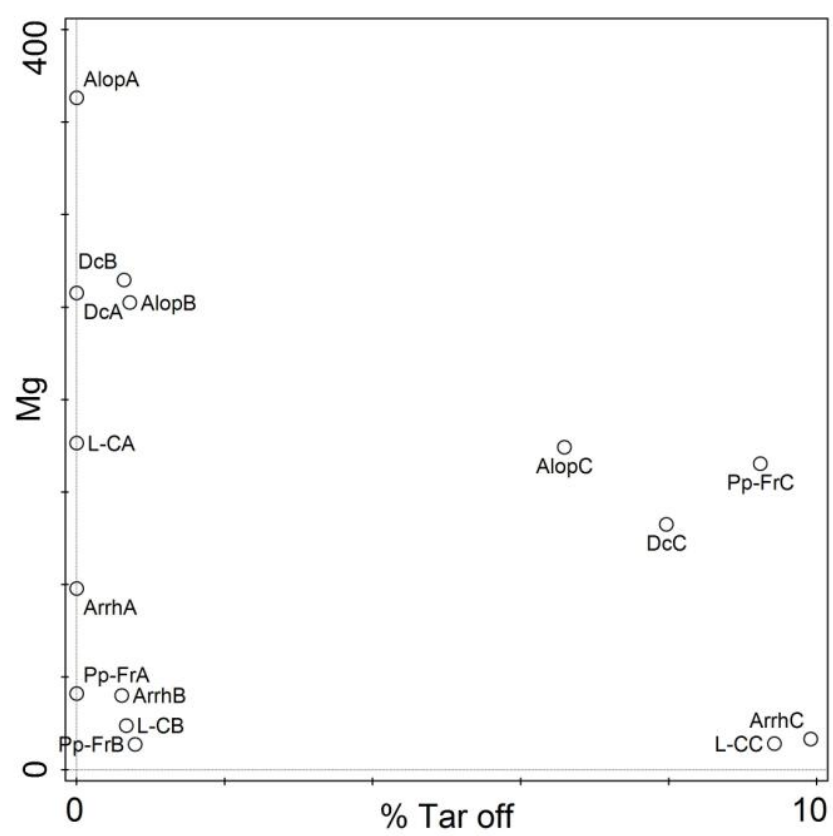

Figure 3. The share of Taraxacum officinale in swards of phytocoenoses depending on soil magnesium content. Explanations under Figure 2. 


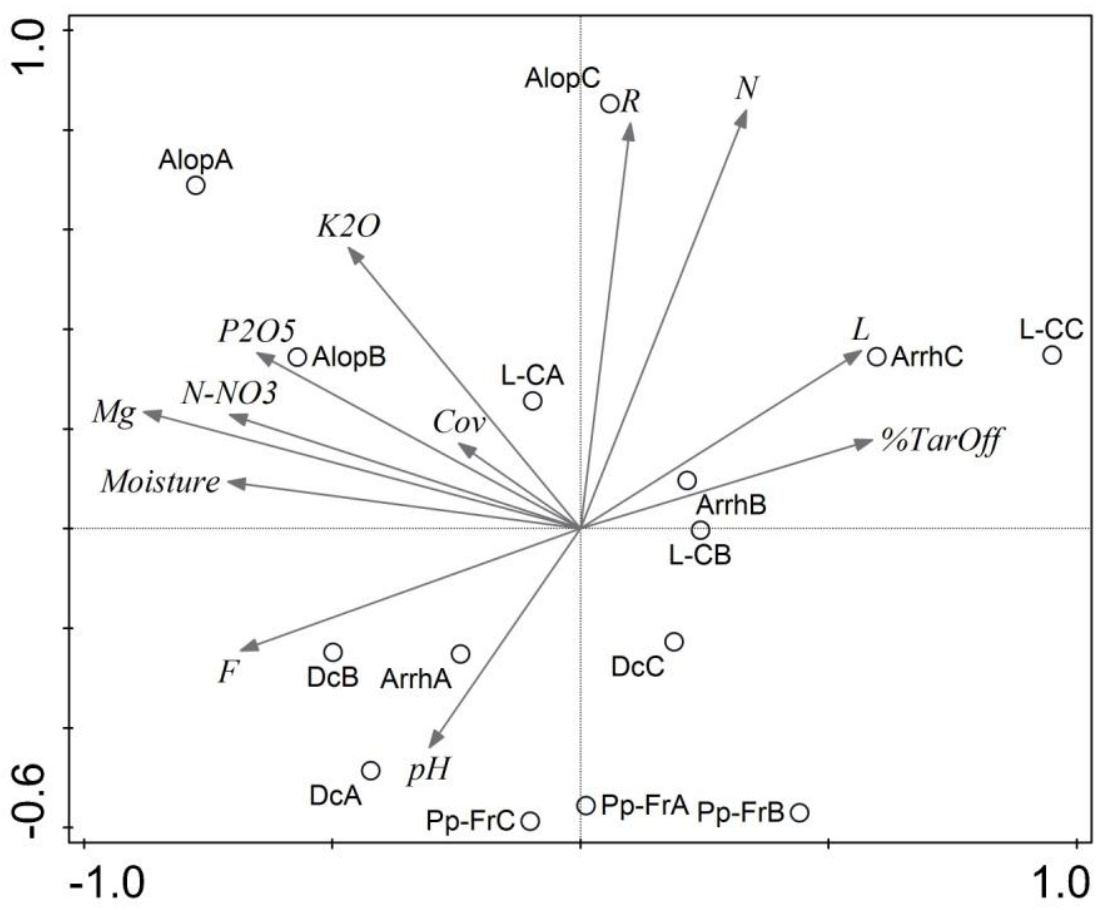

Figure 4. Habitat conditions assessed by laboratory methods and the share of Taraxacum officinale in swards of the phytocenoses. Notes. Moisture - soil moisture content; $p H$ - soil reaction; Cov-cover herb layer; \%TarOff-share of Taraxacum officinale; $\mathrm{Mg}$ - content of available magnesium; $\mathrm{K} 2 \mathrm{O}$ - potassium content; $\mathrm{P} 2 \mathrm{O} 5$ - phosphorus content; $\mathrm{N}$-NO3 nitrogen content; $L-$ Ellenberg's light index; $F$-Ellenberg's moisture content index; $R-$ Ellenberg's $p H$-reaction index; $N$-Ellenberg's nitrogen content index. Other explanations under Figure 2.

Brock et al. (2005) indicated a considerable phenotypic elasticity of Taraxacum officinale in relation to habitat conditions and its potential adaptability to light conditions. At high insolation leaves of this species considerably decrease in size, while at reduced lighting, as observed in denser swards, they elongate significantly. This promotes the occurrence of dandelion in periodically dry areas at strong insolation (Neuteboom and Lantinga, 1991; Brock, 2003).

\section{The presence of Taraxacum officinale in swards of communities and their natural and fodder value}

The presence of Taraxacum officinale in the sward influences both the natural value and utility value of the phytocoenoses. Greater numbers of plant species were recorded in relevés of mowed areas and their number decreased with the increase in the share of common dandelion. Swards used as pastures showed no such dependence. It needs to be stressed that the highest share of species in the sward, irrespective of the manner of use, was recorded at a slight, approx. 1\% share of T.o. (Fig. 5). Similar changes were observed in the values of the calculated Shannon-Wiener index (Table 1).

Generally the presence of Taraxacum officinale to a limited extent positively influences natural value of phytocoenoses - most typically it is low. Only sporadically utilised communities of habitats with a higher moisture content such as communities 
Deschampsia caespitosa and Alopecuretum pratensis at a slight share of Taraxacum officinale present moderate natural value. In turn, this species has a positive effect on the fodder value of mowed sward. Such a dependence was not observed at pasture use (Table 1). It may be assumed that the positive effect on fodder value of sward is a result of the chemical composition of this species, which is reflected in its high palatability (Tsuyuzaki and Takahashi, 2007; Jankowska, 2012; Lukač et al., 2012).

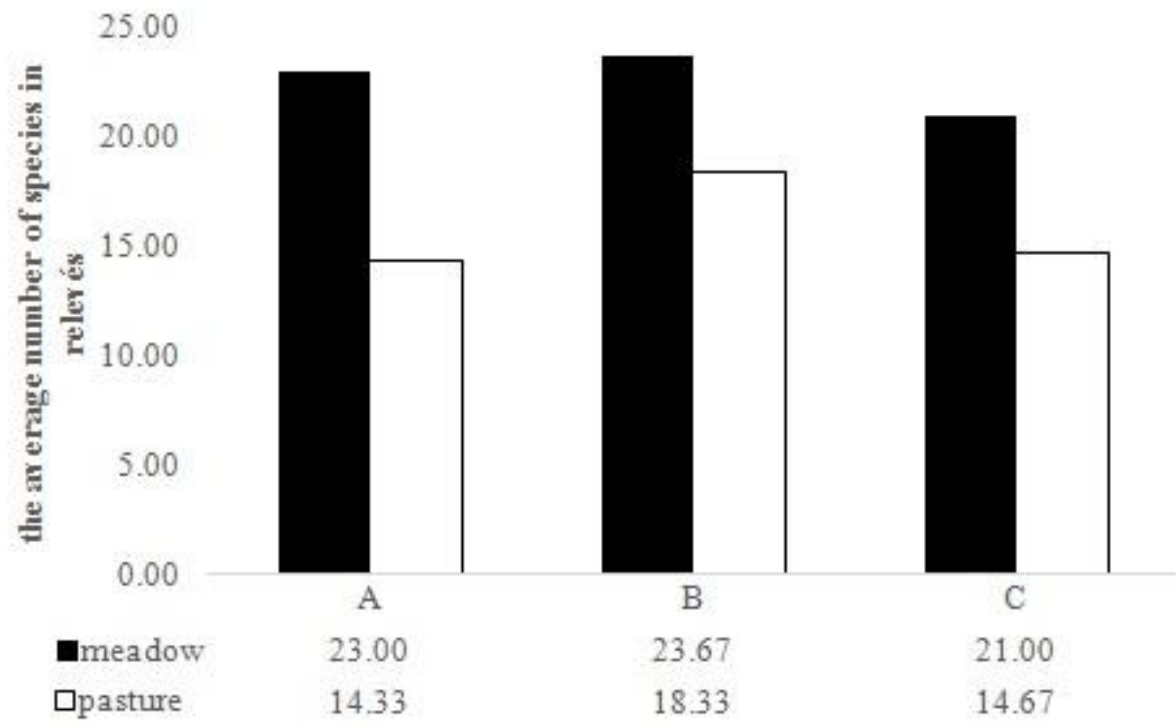

Figure 5. Species richness in phytocenoses with different shares of Taraxacum officinale in sward and different manner of use. Explanations under Figure 1.

Natural and utility value of the plant communities reflect the phytosociological structure of phytocoenoses containing this species. The Principal Component Analysis (Fig. 6) confirmed that an increased share of dandelion in relevés with Deschampsia caespitosa and Alopecuretum pratensis is correlated first of all with a greater share of species from the class Phragmitetea, which is manifested in the higher natural value of these phytocenoses.

Dependencies between all the assessed parameters connected with the share of Taraxacum officinale in swards of analysed communities, i.e. factors determining habitat conditions and its effect on natural and utility value of phytocoenoses is presented synthetically in Fig. 7, which confirms that an increasing share of dandelion in the sward is positively correlated with values of $\mathrm{R}$ and $\mathrm{N}$. In turn, an increase in the share of Taraxacum officinale is accompanied by a greater share of segetal and ruderal species, which is connected with a greater insolation of the area. These factors contribute to the poorer floristic structure of phytocoenoses, as manifested by a lower number of recorded species (Kiss et al. 2011; Beck et al. 2014). It needs to be stressed that the absence of dandelion in the sward is frequently connected with a greater share of species representing the class of Phragmitetea, and thus greater natural values. These areas were also characterised by greater soil resources of available magnesium and phosphorus forms. 


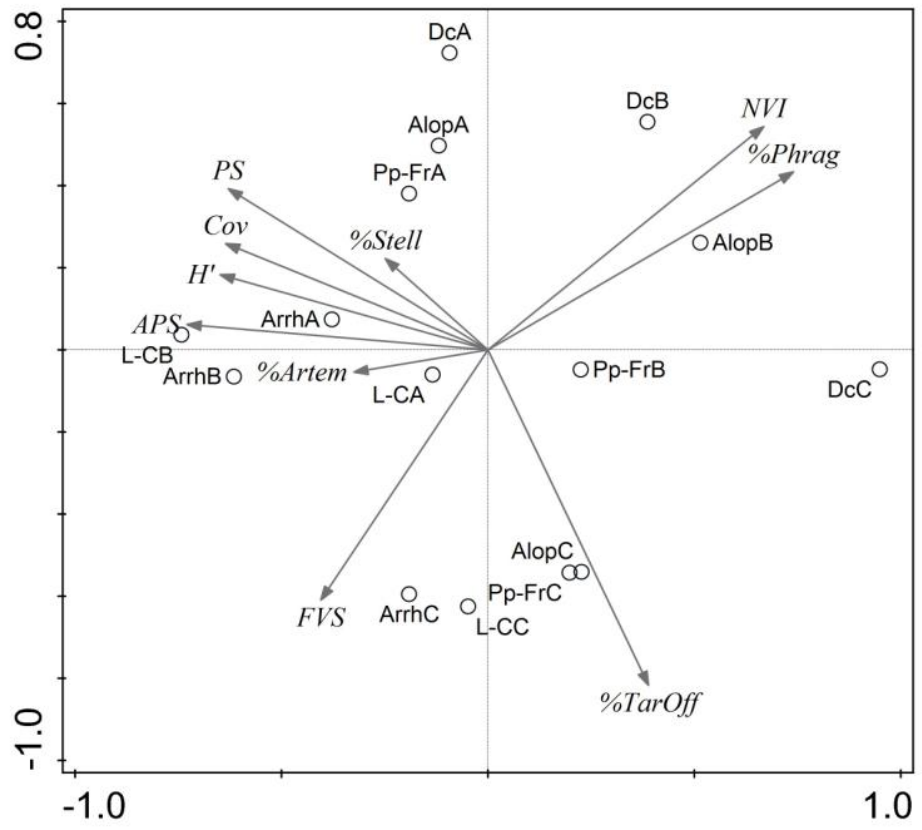

Figure 6. Natural value and utility value of communities with different shares of Taraxacum officinale. Notes. PS - number of plant species generally; APS - average number of plant species in relevés; $H^{\prime}$ - Shannon-Wiener index; FVS-fodder value of sward; NVI-natural value index; \%Stell - share of plant species of Stellarietea mediae class; \%Arterm-share of plant species of Artemisietea vulgaris class; \%Phrag - share of plant species of Phragmitetea class. Other explanations under Figure 2 and 4.

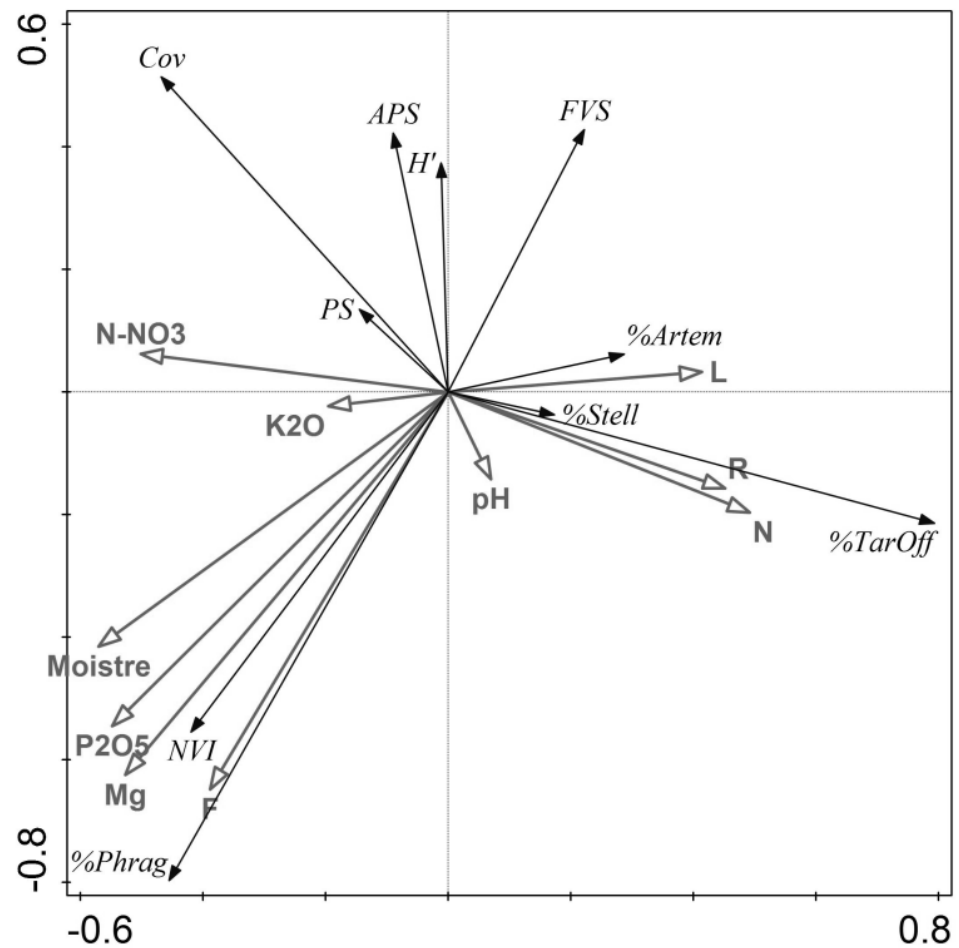

Figure 7. The dependence of the share of Taraxacum officinale on habitat conditions and its effect on natural value and fodder value of sward. Explanations under Figure 4 and 6. 


\section{Conclusion}

Occurrence of common dandelion (Taraxacum officinale F.H.Wigg.) in swards of meadow-pasture communities is promoted by: habitat conditions, particularly soil periodically dry and good insolation, as well as a slightly acidic soil reaction and low contents of available magnesium in soil, pasture use and its lower intensity.

An increased share of common dandelion in phytocenoses of class MolinioArrhenatheretea contributes to a decreased natural value, as manifested in the reduction of floristic diversity, while it has a positive effect on the fodder value of mowed swards.

Acknowledgements. The study was financed from budget resources for science in years 2010-2012 as a research project No. NN 310381439

\section{REFERENCES}

[1] Baker, H.G. (1965): Characteristics and modes of origin of weeds. - In: Baker, H.G., Stebbins, G.L. (eds.) The Genetics of Colonizing Species. International Union of Biological Sciences, Academic Press.

[2] Baker, H.G. (1974): The evolution of weeds. - Annual Review of Ecology and Systematics 5: 1-24.

[3] Barabasz, B. (1994): The effect of traditional management methods modifications on changes in meadows of Molinio - Arrhenatheretea class. - Wiadomości Botaniczne 38 (1-2): 85-94. (in Polish).

[4] Barabasz, B. (1997): Changes in the meadows of the northern part of the Niepołomice forest during twenty years. - Studia Naturae 43: ss. 99. (in Polish).

[5] Beck, J. J., Hernández, D. L., Pasari, J. R., Zavaleta, E. S. (2014): Grazing maintains native plant diversity and promotes community stability in an annual grassland. Ecological Applications 25:1259-1270.

[6] Braak, C.J.F. ter, Šmilauer, P. (2012): Canoco reference manual and user's guide: software for ordination, version 5.0 - Microcomputer Power. Ithaca.

[7] Brock, M.T. (2003): Invasion of high alpine ecosystems by the exotic dandelion Taraxacum officinale (Asteraceae): $\mathrm{PhD}$ thesis. University of Missouri. Columbia, MO, USA.

[8] Brock, M.T., Weining, C., Galen, C. (2005): A comparison of phenotypic plasticity in the native dandelion Taraxacum ceratophorum and its invasive congener T.officinale. - New Phytologist 166: 173-183.

[9] Ellenberg, H, Leuschner, C. (2010): Vegetation Mitteleuropas mit den Alpen in ökologischer, dynamischer und historischer. Sicht. 6. - Aufl. Eugen Ulmer, Stuttgart, Germany.

[10] Filipek, J. (1973): The proposal for the classification of meadow and pasture plants on the basis of fodder value scores. - Postępy Nauk Rolniczych 4: 58-69. (in Polish).

[11] Genovesi, P. (2004): The European Strategy on Invasive Alien Species. - Naturopa 101: 21.

[12] Hennekens, S.M., Schaminee, J.H.J. (2001): TURBOVEG, a coprehensive data base management system for vegetation data. - Journal of Vegetation Science 12: 589-591.

[13] Hill, M.O. (1979): TWINSPAN-A FORTRAN program for arranging multivariate data in an ordered two-way table by classification of the individuals and attributes. - Ecology and Systematics.

[14] Jackowiak, B. (1999): Models of expansion of synanthropic and transgenic plants species. - Phytocenosis 11 Seminarium Geobotanicum 6: 1-24. (in Polish). 
[15] Jankowska, J. (2012): Effect of different of Taraxacum officinale control on the amount and quality of dry matter yield of meadow sward. - Fragmenta Agronomica 29(2): 4351.(in Polish).

[16] Jankowska, J., Ciepiela, G.A., Sosnowski, J., Kolczatek, R., Jankowski, K. (2009): The allelopathic effect of Taraxacum officinale F.G. Wigg. on the sedes germination and initial growth of Lolium westerwoldicum R.Br. - Acta Agronomica 62(2): 207-212.

[17] Kiss, T., Lévai, P., Ferencz, Á., Szentes, SZ., Hufnagel, L., Nagy, A., Balogh, Á., Pintér, O., Saláta, D., Házi, J., Tóth, A., Wichmann, B., Penksza, K. (2011): Change of composition and diversity of species and grassland management between different grazing intensity in Pannonian dry and wet grasslands. - Applied Ecology and Environmental Research 9(3): 197-230.

[18] Klimeš, F., Koláŕ, L., Kobes, M., Voženílková, B. (2003): The impacts of various cultivation methods and permanent grassland use on the changes in Taraxacum officinale Web. cover rate. - Plant Soil and Environment 49(2): 49-54.

[19] Kryszak, A., Kryszak, J., Klarzyńska, A., Strychalska, A. (2009): Influence of Expansiveness of Select Plant Species on Floristic Diversity of Meadow Communities. Polish Journal of Environmental Studies 18(6): 1203-1210.

[20] Lukač, B., Kramberger, B., Meglič, V., Verbič, J. (2012): Importance of non-leguminous forbs in animal nutrition and their ensiling properties: a review. - ZemdirbysteAgriculture 99(1): 3-8.

[21] Magurran, A.E. (1991): Ecological diversity and its measurement. - Chapman and Hall, London.

[22] Martinkova, Z., Honek, A. (2014): The establishment of Taraxacum officinale plants in grassland. - Weed Research 54(5): 501-510.

[23] Matuszkiewicz, W. (2012): A quide to identification of plant communities of Poland. Vademecum Geobotanicum 3: 1-537. (in Polish).

[24] Molina-Montenegro, M. A., Quiroz, C. L., Torres-Díaz, C., Atala, C. (2011): Functional differences in response to drought in the invasive Taraxacum officinale from native and introduced alpine habitat ranges. - Plant Ecology \& Diversity 4(1): 37-44.

[25] Molina-Montenegro, M. A., Palma-Rojas, C., Alcayaga-Olivares, Y., Oses, R., Corcuera, L. J., Cavieres, L. A., Gianoli, E. (2013): Ecophysiological plasticity and local differentiation help explain the invasion success of Taraxacum officinale (dandelion) in South America. - Ecography 36(6): 718-730.

[26] Neuteboom, J. H., Lantinga, E. A. (1991): Population dynamics of Taraxacum officinale in grassland. - Grassland renovation and weed control in Europe. A conference held at Graz, Austria: 163-164.

[27] Oświt, J. (2000): The method of valuation of natural wetlands and the results of its application to selected objects. - Materiały Inforacyjne-Instytut Melioracji i Użytków Zielonych 35: 1-36. (in Polish).

[28] Pysek, P., Prach, K., Rejmanek, M., Wade, M. (eds.). (1995): Plant invasions - General aspects and special problems. - Workshop held at Kostelec nad Černými lesy, Czech Republic.

[29] Szoszkiewicz, K., Szoszkiewicz, J. (1998): Species diversity evaluation of grassland vegetation on the basis of selected communities. - Prace Komisji Nauk Rolniczych i Komisji Nauk Leśnych PTPN 85: 47-51. (in Polish).

[30] Tichý, L. (2002): JUICE, software for vegetation classification. - Journal of Vegetation Science 13: 451-453.

[31] Tsuyuzaki, S., TakahashiH. (2007): Pits converse species diversity in an overgrazed grassland. - Applied Ecology and Environmental Research 5(2): 25-36.

[32] Vavrek, M. C., McGraw, J. B., Yang, H. S. (1996): Within-population variation in demography of Taraxacum officinale: maintenance of genetic diversity. - Ecology 20982107. 